
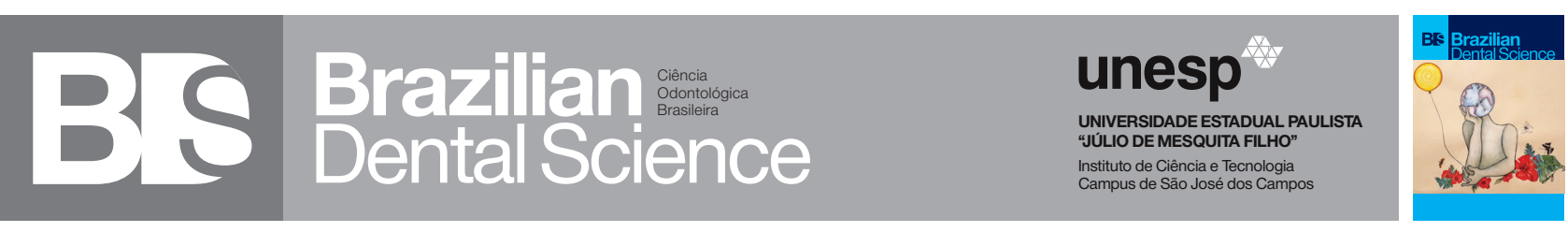

\title{
Effect of immediate dentin sealing, bonding technique, and restorative material on the bond strength of indirect restorations
}

Efeito do selamento imediato da dentina, técnica de união e material restaurador na resistência de união de restaurações indiretas

Bilal Utku SAG ${ }^{1}$, Ozden Ozel BEKTAS ${ }^{1}$

1 - Department of Restorative Dentistry and Endodontics - Faculty of Dentistry - Cumhuriyet University - Sivas - Turkey.

\section{ABSTRACT}

Objective: The objective of this study was to evaluate the effect of immediate dentin sealing, bonding technique, and restorative material on the dentin bond strength of an indirect composite (Solidex) and a resin nanoceramic CAD/CAM block (LAVA Ultimate). Material and Methods: A total of 120 periodontally extracted human molar teeth were abraded horizontally and divided into two groups according to dentin sealing procedures (delayed dentin sealing [DDS] and immediate dentin sealing [IDS]). Next, all teeth were attached to a simulated pulpal pressure mechanism. The specimens were removed from the mechanism after a week. Teeth were subdivided into three groups based on the bonding technique and the type of cement used (Acid-etching + Single Bond Universal + RelyX Ultimate, Single Bond Universal + RelyX Ultimate, RelyX Unicem). Each subgroup was further divided into 2 subgroups according to the type of restorative material used (Solidex $[n=10]$, Lava Ultimate CAD/ CAM restorative material $[n=10])$. Sixty cylindrical samples prepared using both the restorative materials were bonded to the tooth surface according to their group's bonding procedures. All specimens were embedded in chemically cured acrylic resin for shear bond strength test. The shear bond strength (SBS) of the specimens was determined by a universal testing machine with a headspeed of $0.5 \mathrm{~mm} / \mathrm{min}$. Results: Three-way ANOVA, independent-sample $t$ test and post hoc Tukey comparison tests $(\alpha=0.05)$ were performed on all data. There were significant differences between the groups. It was found that IDS process significantly increased bond strength in all groups. When dentin bond strengths of tested

\section{RESUMO}

Objetivo: O objetivo deste estudo foi avaliar o efeito do selamento imediato da dentina, da técnica adesiva e do material restaurador na resistência de união à dentina de um compósito indireto (Solidex) e um bloco CAD / CAM de resina nanocerâmica (LAVA Ultimate). Material e Métodos: Um total de 120 dentes molares humanos extraídos por razões periodontais foram desgastados horizontalmente e divididos em dois grupos de acordo com os procedimentos de selamento dentinário (vedação tardia da dentina [DDS] e vedação imediata da dentina [IDS]). Em seguida, todos os dentes foram conectados a um equipamento de pressão pulpar simulada. As amostras foram removidas do equipamento após uma semana. Os dentes foram subdivididos em três grupos, com base na técnica de união e no tipo de cimento utilizado (ataque ácido + Single Bond Universal + RelyX Ultimate, Single Bond Universal + RelyX Ultimate, RelyX Unicem). Cada subgrupo foi então dividido em 2 subgrupos de acordo com o tipo de material restaurador utilizado (Solidex [n $=10]$, material restaurador Lava Ultimate CAD / CAM [n $=10]$ ). Sessenta amostras cilíndricas preparadas com os dois materiais restauradores foram coladas na superfície do dente de acordo com os procedimentos de adesão do grupo. Todas as amostras foram embebidas em resina acrílica quimicamente ativada para o teste de resistência ao cisalhamento. A resistência de união ao cisalhamento (SBS) das amostras foi determinada por uma máquina de teste universal com uma velocidade de $0,5 \mathrm{~mm} / \mathrm{min}$. Resultados: ANOVA de três fatores, teste $t$ de amostra independente e testes de comparação post hoc de Tukey $(\alpha=0,05)$ foram realizados em todos os dados. Houve diferenças significativas entre os grupos. Verificou-se que o processo IDS aumentou significativamente a força de união em todos os grupos. Quando as forças de união 
luting cements were compared, the highest bond strength values were recorded in groups in which the specimens were luted with RelyX Ultimate cement using etch-and-rinse technique. The lowest bond strength values were obtained from groups that used RelyX Unicem as the luting cement. Conclusion: IDS improves bond strength of indirect restorations. Moreover, bonding techniques may have critical effects on the dentin bond strength of indirect restorative materials. The cements' specific affinity levels to both restorative materials and dentin could be considered as the reason of the situation.

\section{KEYWORDS}

IDS; Luting cement; Shear bond strength; Resin nanoceramic; CAD/CAM. da dentina dos cimentos testados foram comparadas, os valores mais altos de força de união foram registrados nos grupos em que as amostras foram cimentadas com cimento RelyX Ultimate usando a técnica "condicione e lave". Os menores valores de resistência de união foram obtidos de grupos que usaram como cimento o RelyX Unicem. Conclusão: O IDS melhora a força de união das restaurações indiretas. Além disso, as técnicas de união podem ter efeitos críticos na resistência da união à dentina de materiais restauradores indiretos. Os níveis de afinidade específicos dos cimentos para materiais restauradores e dentina podem ser considerados $\mathrm{o}$ motivo da situação.

\section{PALAVRAS-CHAVE}

IDS, cimentação; resistência ao cisalhamento; resina nanocerâmica; CAD / CAM

\section{INTRODUCTION}

D irect and indirect resin composite restorations are widely used in contemporary dentistry to restore posterior teeth [1, 2]. Composites are limited for direct restoration of the larger stress-bearing posterior Class II cavities owing to their polymerization shrinkage effects and a few limitations in their mechanical properties [3]. Indirect restorations are indicated for large cavities, where the width of the isthmus exceeds two-thirds of the distance between the facial and lingual cusp tips $[1,2,4]$. Several factors need to be considered while applying indirect restorations, such as the restorative material, adhesive cementation to dentin/enamel, and the bonding procedures [5]. Recent developments in material science technology have considerably improved the physical properties of resin-based composite cements, thereby expanding their clinical applications. These can be divided into direct and indirect resin composites (IRC). IRC are also called prosthetic composites or laboratory composites [6]. These are polymerized using laboratory polymerization units. Indirect composites are cured outside the mouth; hence, they allow the use of highenergy ultraviolet (UV) light for performing this extraoral polymerization procedure $[7,8]$.
Achieving a proper interproximal contact and complete cure of the composite resins in the deepest regions of a cavity are the challenges related to direct composite restorations [6].

During the last decade, we have witnessed a dramatic increase in the use of computeraided design and manufacturing (CAD/ CAM) in dentistry; this increase was possibly triggered by spectacular advances in intra-oral imaging and manufacturing technologies, and by environmental concerns related to the byproducts of the classic manufacturing process of indirect dental restorations [9]. Ceramics and composite resins are the two main groups of $\mathrm{CAD} / \mathrm{CAM}$ restorative materials [10]. Resin composite block materials offer significant advantages that are related to their manufacturability, machinability, and repeatability $[9,11]$. The manufacturing purpose of these new generation materials is to combine the advantages of ceramics and composites in the same material [12]. Among these materials, LAVA Ultimate (3M ESPE, St. Paul, MN, USA) is a resin nanoceramic (RNC) that is composed of nanoceramic particles embedded in a highly cross-linked resin matrix [13].

Conversely, bonding to the dentin is essential for the success of these materials. In 
current clinical practice, there are three available resin cements in the market classified according to their adhesive characteristics. These are the etch-and-rinse resin cements-also called totaletch cements, the self-etch resin cements, and the self-adhesive resin cements [14].

The etch-and-rinse adhesive strategy is a complex, multi-step technique; however, it provides a high bond strength. Self-etching systems involve the application of a selfetching primer to the prepared tooth surfaces, and the mixed cement is applied over the primer. The newest resin cements are the selfadhesive resin cements that require no etching, primers, or bonding agents for bonding to the tooth surface. These materials were designed to overcome the limitations of both traditional and resin-based cements and simplify the bonding procedures $[14,15]$.

More recently, dentists have been able to use dentin adhesives according to their own judgment or tailored to a specific clinical situation. These new adhesives are known as "universal" adhesives, as they can be used as self-etch adhesives, etch-and-rinse adhesives, or with a selective enamel etching approach [16]. Universal adhesives have been realized to incorporate all possible techniques for the treatment of the dentin/enamel/restoration surface using a single product $[16,17]$ and are used in combination with a resin cement [18].

Additionally, immediate dentin sealing (IDS) technique, in which the bonding agent is directly applied after tooth preparation, has been recommended for indirect bonded restorations. Sealing of dentinal tubules with a filled adhesive resin directly after tooth preparation and prior to obtaining an impression (digital or analogue) is presumed to result in an improved bond strength, less gap formation, decreased bacterial leakage, and reduced dentin sensitivity $[19,20]$. Currently, there is very limited data about bonding properties of the current CAD/CAM composites. It can be anticipated that IDS would support the bond strength of indirect restorations.

Therefore, the objective of this study was to compare the bond strength of different resin cements on an indirect composite and a resin nanoceramic CAD/CAM block with and without IDS application. The tested null hypotheses were twofold, which are as follows: (1) IDS application produces no difference in the bond strength of indirect restorations; (2) The type of resin cement systems with different restorative materials has a significant effect on the shear bond strength (SBS).

\section{MATERIAL AND METHODS}

The present study was approved by the Ethics Committee at Cumhuriyet University (Protocol No. 12/18, 24.12.2013). The SBS test was carried out following the guidelines of ISO/TS 11405:2003.

\section{Tooth Preparation}

In this study, 120 periodontally extracted, caries-free, human molar teeth were selected, which were cleaned for both calculus and soft tissues, and were stored in distilled water at $4{ }^{\circ} \mathrm{C}$ for no longer than 1 week. Teeth were abraded occlusally for achieving mid-coronal dentin exposure with a $1.4 \mathrm{~mm}$ diamond bur (SF 11C, Fischer, Centreville, ABD) at 1.5 bar pressure under water spray coolant. The tooth crown was separated from the root by cutting at $1 \mathrm{~mm}$ below the cemento-enamel junction for accessing pulp chamber. Remaining pulp deposits were cleaned with a college tweezer. In order to attach the specimens to simulated pulpal pressure mechanism, the holes, which were $2 \mathrm{~mm}$ deep and $3 \mathrm{~mm}$ in diameter, were drilled at the base of each crown's pulp chamber at the same speed and pressure.

The specimens were randomly divided into two groups according to the resin coating procedures (IDS and DDS). Each group was subdivided into three groups according to the bonding techniques and cement types used: RelyX Ultimate Clicker (3M ESPE, ABD) (Acid + Single Bond + RUL and SB+RUL groups) and RelyX Unicem (3M ESPE, ABD) (RUN groups). Further, each subgroup was divided into two subgroups based on the restorative materials: LAVA Ultimate CAD/CAM Restorative Blocks (3M ESPE, St Paul, MN, ABD) (LAVA groups) and Solidex (SHOFU INC, Kyoto, Japan) (SOL groups). Experimental groups varied according to the sequence and mode of applications as shown in Figure 1. 


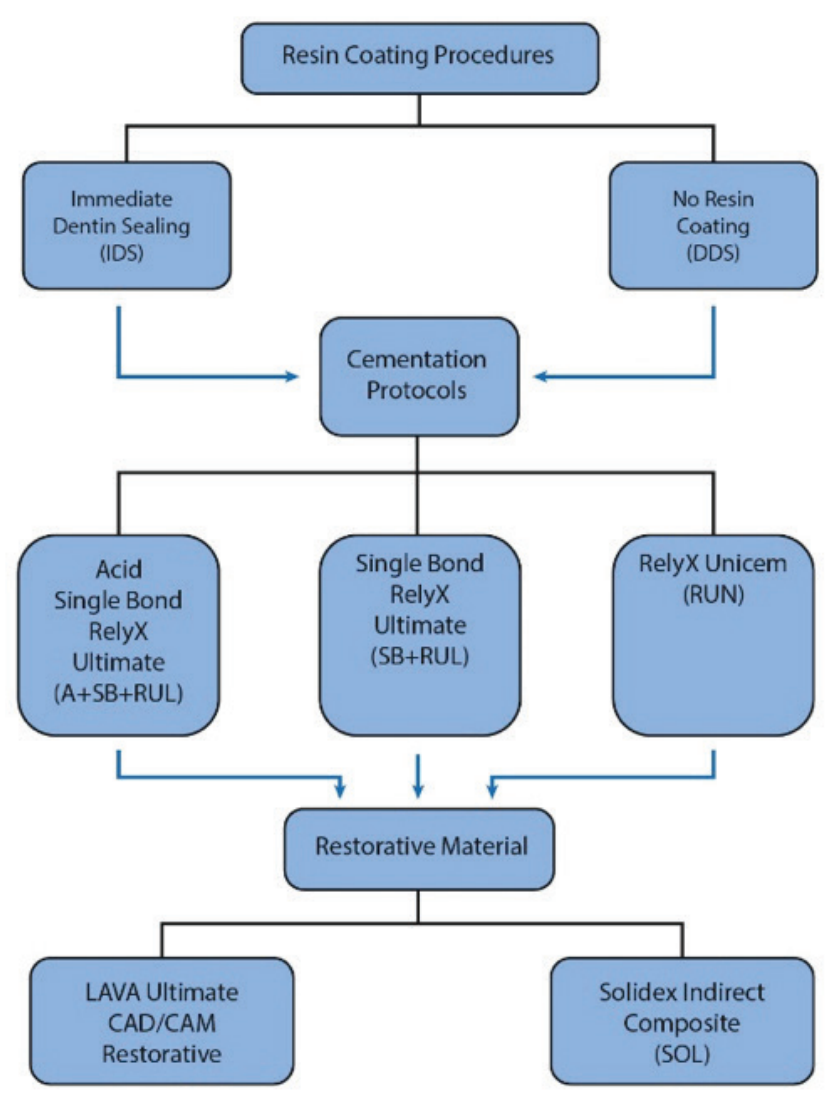

Figure 1 - Experimental groups.

\section{Restoration Fabrication}

Digital media drawings of cylindrical LAVA specimens with a diameter of $3 \mathrm{~mm}$ and a height of $3 \mathrm{~mm}$ were created using YenaDent Cam 4.0 software (PicaSoft SAS, Vierzon, France). Considering the dimensions of the blocks to be cut, it was decided to mill three samples per block. The precision attachment localization was designed to be one pair per specimen between the side walls of the cylindrical samples and the block in order to secure the bonding surface (Figure 2). The milling process was performed by Yenadent D40 CAD/CAM device (Yena Makine San. ve Tic. Ltd., Istanbul, Turkey). LAVA Ultimate blocks were fixed to the device in groups of three using the System 3R apparatus. Sixty cylindrical LAVA specimens were successfully machined from 20 blocks.

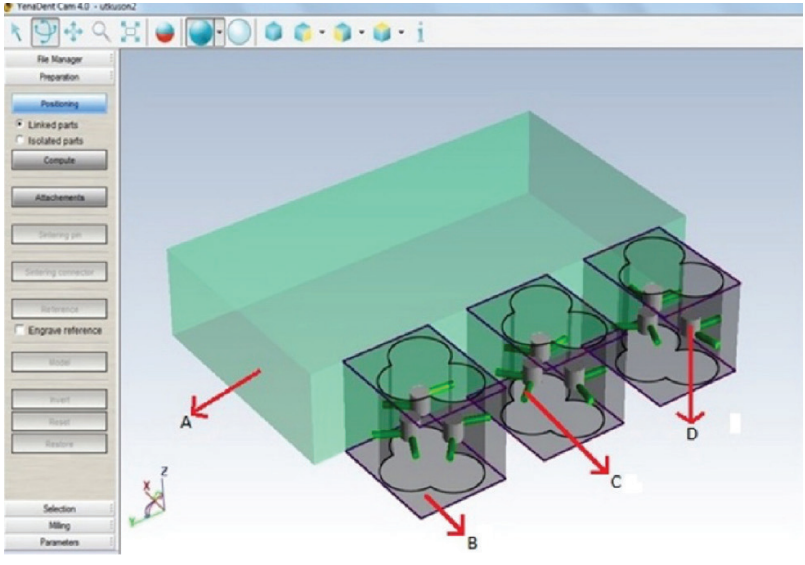

Figure 2 - Screen shot of digital media drawing of cylindrical LAVA specimens. A: System 3R Apparatus B: LAVA Ultimate Block C: Precision Attachment D: Cylindrical Specimen.

To obtain the same size and height of 60 samples, plastic molds were used in fabrication of Solidex IRC specimens. These molds were placed on a cement glass with a polyester strip tape on it. After the composite material was placed into the mold with a pitch applicator, another polyester strip and the cement glass were placed on the composite resin. Subsequently, all specimens were polymerized for $180 \mathrm{sec}$ with a light wave spectrum of 400-550 nm in Solidilite V lightcuring unit (SHOFU INC, Kyoto, Japan).

\section{Procedure}

\section{Immediate Dentin Sealing (IDS)}

For IDS groups, the procedure was completed in two steps, as follows: (1) freshly cut dentin surface was coated with the selfetching adhesive, Clearfil SE Bond (Kuraray Medical, Tokyo, Japan); (2) next, a $1 \mathrm{~mm}$ thick layer of low-viscosity composite resin, Filtek Ultimate Flowable (3M ESPE, St Paul, $\mathrm{MN}, \mathrm{ABD}$ ), was applied according to the manufacturer's instructions. For DDS groups, no coating was done and all teeth in both the groups were sealed with the temporary filling material, Diatemp (DiaDent, Buk-do, Korea) (Table I). 
Table I - Materials used in the present study

\begin{tabular}{|c|c|c|c|}
\hline Materials applied & Type & Manufacturer & Composition \\
\hline $\begin{array}{l}\text { Lava Ultimate CAD/CAM } \\
\text { Restorative }\end{array}$ & Resin nano CAD-CAM block & 3M ESPE, StPaul, MN, ABD & $\begin{array}{l}\text { Silica nanomers }(20 \mathrm{~nm}) \text {, zirconium nanomers (4-11 nm),Silane coupling agent, } \\
\text { Zirconia/Silica nanoceramic particles ( } 80 \mathrm{wt} \%) \text {, resin matrix (UDMA) (20 wt\%) }\end{array}$ \\
\hline Solidex & Indirect composite material & SHOFU INC, Kyoto, Japan & $\begin{array}{l}\text { Matrix: UDMA, HEMA, Bis-GMA EGDMA (\%25) } \\
\text { Filler Content: Inorganic ceramic, silicon dioxide and aluminum dioxide particles } \\
\text { (\%22) }\end{array}$ \\
\hline RelyX Unicem & $\begin{array}{l}\text { Dual-polymerizing self-adhesive } \\
\text { resin cement }\end{array}$ & 3M ESPE, StPaul, MN, ABD & $\begin{array}{c}\text { Powder: Alkaline and silane fillers, starting components, pigments } \\
\text { Liquid: Phosphoric acid methacrylates, methacrylate monomers, starting com- } \\
\text { ponents, stabilizers } \\
\text { Application technique: clean tooth surface with pumice and water, air dry 2-3 } \\
\text { seconds to remove pooled water, mix cement } 10 \text { s, apply cement and polymerize } \\
20 \text { s. }\end{array}$ \\
\hline \multirow{3}{*}{ RelyX Ultimate Clicker } & Adhesive resin cement & 3M ESPE, StPaul, MN, ABD & $\begin{array}{l}\text { Base: Methacrylate monomers, silanated fillers, initiators, stabilizers } \\
\text { Catalyst: Methacrylate monomers, alkaline fillers, pigments, rheological additives, } \\
\text { Dual-cure activator } \\
\begin{array}{c}\text { Application technique: the base and catalyst were mixed equally onto the mixing } \\
\text { paper for } 10 \mathrm{~s} \text {. Then the mixture applied to samples and polymerize } 20 \mathrm{~s} \text {. }\end{array}\end{array}$ \\
\hline & Scotchbond Etchant (Acid gel) & 3M ESPE, StPaul, MN, ABD & $\begin{array}{c}\text { 37\% phosphoric acid gel } \\
\text { Application technique: apply dentin surface for } 15 \text { s, rinse with air and water for } \\
15 \mathrm{~s} \text {. }\end{array}$ \\
\hline & $\begin{array}{l}\text { Single Bond Universal } \\
\text { (Universal adhesive) }\end{array}$ & 3MESPE, StPaul, MN, ABD & $\begin{array}{l}\text { HEMA, Bis-GMA, dimethacrylate resin, methacrylate-modified polycarbosylic } \\
\text { acid, copolymer, initiator, water, ethanol } \\
\text { Application technique: apply the dentin for } 20 \text { s, gently air dry for } 5 \text { s and polyme- } \\
\text { rize } 20 \mathrm{~s} \text {. }\end{array}$ \\
\hline Clearfil SEBond & $\begin{array}{l}\text { Two-step self-etching adhesive } \\
\text { system }\end{array}$ & Kuraray Medical, Tokyo, Japan & $\begin{array}{c}\text { Primer: MDP,HEMA, hydrophilic dimethacrylate, } \\
\text { DL-camphorquinone, N, N-Diethanol-p-toluidine, water } \\
\text { Bond: MDP, Bis-GMA, HEMA, hydrophobic dimethacrylate, camphorquinone, N, } \\
\text { N-Diethanol-p-toluidine, silanated colloidal silica } \\
\text { Application technique: the primer was applied for } 20 \mathrm{~s} \text { and air dry for } 5 \mathrm{~s} \text {. The } \\
\text { adhesive was then applied and light polymerized for } 15 \mathrm{~s} \text {. }\end{array}$ \\
\hline Filtek Ultimate & Low-viscosity composite resin & 3MESPE, StPaul, MN, ABD & $\begin{array}{l}\text { BisGMA, TEGDMA, procrylate resins, silica fillers } \\
\text { Application technique :applied onto the dentin for } 1 \mathrm{~mm} \text { thickness and polimeri- } \\
\text { sed for } 40 \mathrm{~s} \text {. }\end{array}$ \\
\hline DiaTemp & Temporary filling material & DiaDent, Buk-do, Korea & $\begin{array}{l}\text { Polyurethane dimethacrylate, hydrophilic methacrylate, nano silica and silver, } \\
\text { catalysts, stabilizer } \\
\text { Application technique:placed onto dentin and light cured for } 40 \mathrm{~s} .\end{array}$ \\
\hline
\end{tabular}

\section{Mechanism \\ Simulated Pulpal Pressure (SPP)}

This mechanism was developed for the purpose of simulating in-vivo conditions on the dentin surface [21]. After applying the temporary filling material, the tip of a $10 \mathrm{~cm}$ long semitransparent silicone tube was inserted through the hole created in each tooth's pulp chamber and was fixed using modeling wax. Distilled water was added into the tubes with a dental injector. These 60 tubes were attached with each other by T-shaped pneumatic pipes (Yonggao Co., Zhejiang, China). Handmade "U" manometers were placed at the beginning and toward the end of the system for pressure control. A 1/8 NPT flow regulating valve (Pneumadyne Inc., North Plymouth, MN) was placed at the end of the system to adjust the level of air escape. Next, an aquarium pump (OF, Z-2000, Osaka, Japan) with two outlets was connected to generate $15 \mathrm{~cm}$ water pressure (Figure 3). Thus, each specimen was exposed to hydraulic pressure which delivered $15 \mathrm{~cm}$ water pressure. This procedure was repeated twice and a total of 120 teeth were exposed to distilled water under $15 \mathrm{~cm}$ water pressure for 7 days. 


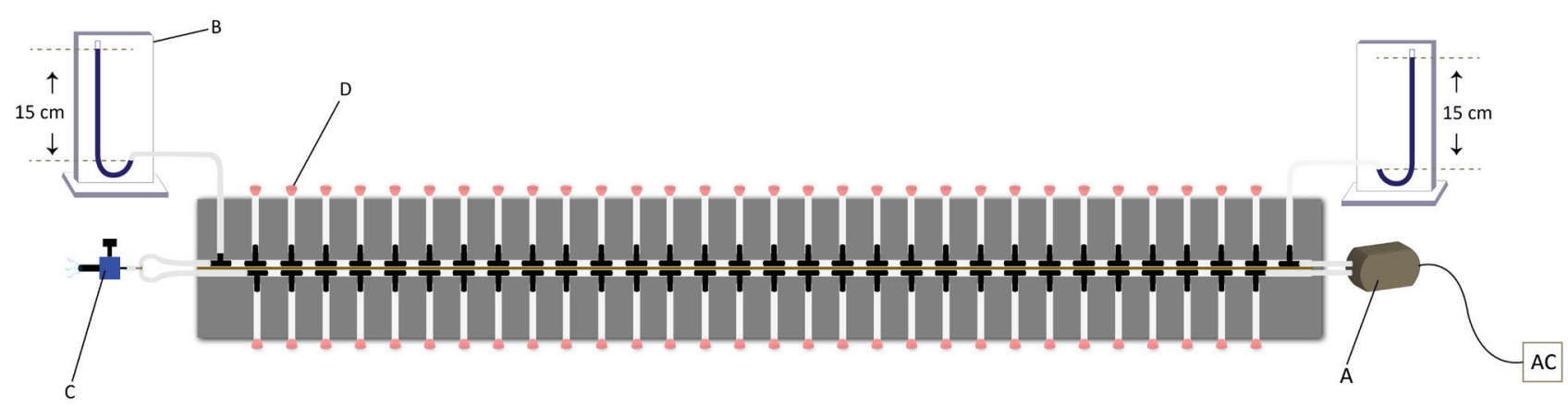

Figure 3 - The image of the pulpal pressure test assembly while operating. A: Aquarium pump B: Handmade "U" manometer C: 1/8 NPT flow regulating valve D: Specimen.

\section{Cementation Protocols}

The teeth were separated from SPP mechanism at the end of 7 days. After temporary filling materials were removed, the teeth in each group were fixed to silicone impression material for the ease of application. Subsequently, the LAVA and Solidex specimens were luted onto each tooth using two different cement types (RUL and RUN) according to the manufacturer's instructions (Table 1). The bases of the cylindrical specimens were cemented to the dentin approximately $2 \mathrm{~mm}$ away from the dentino-enamel junction, perpendicular to the long axes of the teeth and parallel to the occlusal surfaces. In RUL cementation protocol, SB Universal (3M ESPE, ABD) was used as a bonding agent and applied using both self-etch and etchand-rinse techniques. Bonding systems and luting cements were polymerized by an LED light source, VALO Cordless (Ultradent Products, South Jordan, UT, USA) with a light intensity of 395-480 nm.

\section{Load Testing}

Each tooth was fixed with an autopolymerizing acrylic resin (Imicryl, Konya, Turkey) with the long axis perpendicular to the base of copper molds with a diameter of $15 \mathrm{~mm}$ and a height of $20 \mathrm{~mm}$ and subjected to vertical load to fracture using universal testing machine (LF Plus, LLOYD Instruments, Ametek Inc., Leicester, UK). The force was applied in a direction parallel to the occlusal surface with a blunt shear-tip that was bound to the moving part of the device. Bond strength was determined in shear mode at the crosshead speed of $0.5 \mathrm{~mm} / \mathrm{min}$ and the maximum load of $50 \mathrm{kgf}$ until fracture. The maximum force at break point was recorded in MPa with Nexygen software (LLOYD Instruments, UK).
Bond strength values were submitted to three-way analysis of variance (ANOVA) considering the factors dentin sealing, bonding technique and restorative material (2X3X2).

\section{SEM Evaluation}

In order to examine the interface morphology, the samples-prepared according to the cementation protocols-were cut from the occlusal surfaces equally and perpendicularly, using Isomet cutting device (Buehler Ltd, Lake Bluff, IL, USA).. The dentin surfaces of the specimens were then abraded with LaboPol polishing device (Struers, Ballerup, Denmark) for $15 \mathrm{sec}$. Next, DiaPro diamond suspension (Struers, Ballerup, Denmark) was applied and the surfaces were polished for 1 minute. The abrasion and polishing times for all samples were kept constant to ensure standardization.

\section{Statistical Analysis}

Three-way ANOVA, independent-sample $\mathrm{t}$ test and post hoc Tukey comparison tests $(\alpha=0.05)$ were performed to determine the effect of IDS on dentin bond strength of an indirect composite and a resin nanoceramic CAD/CAM block luted with three different cementation protocols.

\section{RESULTS}

\section{SBS}

Table II shows the general group comparison for the mean SBS values (MPa) and standard deviations (SD) of IDS and DDS groups, regardless of the cement type and the restorative material used. Independent-sample t test revealed that IDS had significantly higher SBS values than DDS ( $\mathrm{p}$ $=0.001$ ). 
Table II - Mean SBS values and Standard deviation of IDS and DDS groups

\begin{tabular}{ccccc|}
\hline Groups & N & Mean Value & SD & Result \\
\hline IDS & 60 & 18,57 & $\pm 4,72$ & $t=4,32$ \\
\hline DDS & 60 & 14,89 & $\pm 4,60$ & $p=0,001$ \\
\hline
\end{tabular}

Table III shows the mean and SD of SBS for each of the subgroups. According to three-way ANOVA and Tukey test results, bond strength was significantly influenced by the factors dentin sealing $(\mathrm{F}=31,88 ; \mathrm{p}=0,001)$, bonding technique $(\mathrm{F}=13,99 ; \mathrm{p}=0,001)$ and restorative material $(F=9,73 ; p=0,002)$.The subgroups in which RUL+SOL were used revealed significantly higher SBS values than those that used RUL+LAVA. The opposite occurred for RUN subgroups. The subgroup that used RUN+LAVA demonstrated significantly higher SBS values than that using RUN+SOL $(\mathrm{p}<0.05)$.

Table III - Dentin Bond Strength Values in MPA (SD) for different dentin conditions (IDS and DDS) and different cementation protocols for luting two restorative materials

\begin{tabular}{|c|c|c|c|c|c|}
\hline \multicolumn{3}{|c|}{ IDS } & \multicolumn{3}{|c|}{ DDS } \\
\hline \multirow{2}{*}{$\begin{array}{l}\text { Bonding } \\
\text { Technique }\end{array}$} & \multicolumn{2}{|c|}{ Restorative Material } & \multirow{2}{*}{$\begin{array}{l}\text { Bonding } \\
\text { Technique }\end{array}$} & \multicolumn{2}{|c|}{ Restorative Material } \\
\hline & LAVA & SOL & & LAVA & SOL \\
\hline$A+S B+R U L$ & $17,79(3,35)^{\mathrm{aA}}$ & $22,00(3,76)^{\text {bA }}$ & $A+S B+R U L$ & $13,90(2,51)^{2 \mathrm{~A}}$ & $20,04(4,39)^{\text {bA }}$ \\
\hline SB+RUL & $15,36(3,13)^{\mathrm{aA}}$ & $22,44(3,82)^{b A}$ & SB+RUL & $14,11(2,05)^{\mathrm{aA}}$ & $17,63(4,27)^{\mathrm{bA}}$ \\
\hline RUN & $19,74(4,90)^{\mathrm{aB}}$ & $14,08(2,52)^{\mathrm{bB}}$ & RUN & $13,43(3,87)^{\mathrm{aB}}$ & $10,22(3,06)^{b B}$ \\
\hline
\end{tabular}

Same letters in lowercase indicate no statistical difference on lines, and in uppercase indicate no statistical difference on columns $(p>0.05)$

\section{SEM}

Figure 4 shows representative SEMs for the resin-dentin interface morphologies observed for different tested groups.

For groups restored using RUL with IDS, both images show the polymerized flowable composite material on a smooth adhesive layer (Figures 4A, 4B). No hybrid layer formation was observed. However, when DDS was applied with etch-and-rinse technique, a uniform and regular hybrid layer was observed (Figure 4C). The fracture at the interface of the cement and the restorative material, which possibly occurred during the cutting process, is indicated by an arrow (Figure 4D).

For the self-adhesive resin cement RUN, irrespective of whether the IDS was performed, it was observed that the resin cement had very limited ability to demineralize the dentin surface and consequently, the interaction of the cement with the dentin tissue was weak. No hybrid layer formation was observed (Figure 4E, 4F).
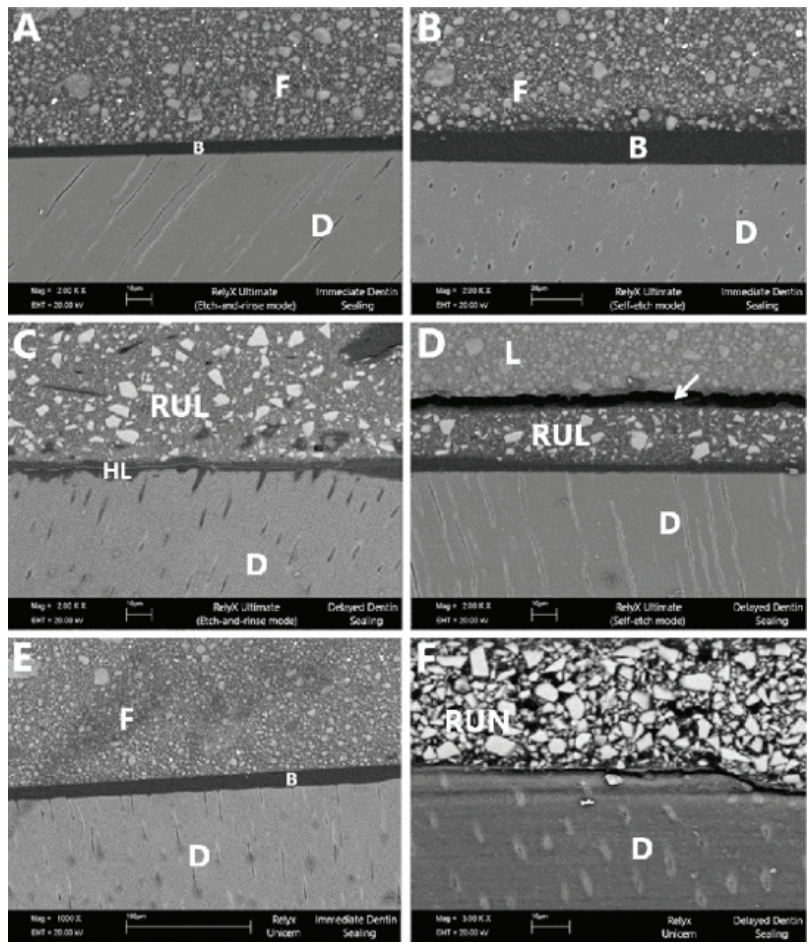

Figure 4 - Representative SEMs of specimens luted with etch and rinse cement RelyX Ultimate (A,B,C,D): IDS. (A and B): DDS. (C and D) and the self adhesive cement RelyX Unicem (E,F): IDS. (E): DDS. (F). B: Adhesive layer, D: Dentin, F: Flowable composite, L: LAVA Ultimate, HL: Hybrid layer. The arrow indicates the gap between the restorative material and cement. 


\section{DISCUSSION}

The conventional way of bonding indirect restorations to dentin by using resin cement has been called "Delayed Dentin Sealing." This procedure depends on late dentinal cementation after a temporary restorative period. However, this method does not provide the optimum conditions for bonding and dentin contamination causes decreased bond strength between the restorations and dentin substrate [22,23]. To obtain ideal cementation efficiency, various techniques have been developed by the researchers. The idea of bonding dentin layer right after the preparation and prior to taking the impression, the so called "Immediate Dentin Sealing" [20, $24,25]$ provides significant advantages. IDS can result in significantly increased retention when combined with glass-ionomer or resinmodified cements [26]. It also reduces marginal leakage, postoperative sensitivity, and bacterial contamination through sealing of freshly cut dentinal tubules during the provisional phase $[20,27,28]$. Duarte et al reported that MOD inlay cavities with IDS application demonstrated significantly higher bonding strength than those with DDS application [29]. Choi et al also reported that the IDS recorded higher values on SBS than the DDS with regard to porcelain restorations [30].

This study followed the IDS bonding procedure as suggested by Magne et al. [25] and Duarte et al. [31]. These studies demonstrated that IDS using a self-etch primer adhesive system combined with a low-viscosity composite liner may provide a better sealing of the dentinal tubules. Furthermore, these studies reported that the low-viscosity composite layer helps in protecting the underlying hybrid layer [20]. Same has been followed in this study after applying Clearfil SE Bond followed by the application of Filtek Ultimate Flowable.

In our study, all IDS groups showed significantly higher bonding strength values compared to those of the DDS groups. Thus, the first null hypothesis - that IDS application does not cause any difference in the bond strength of indirect restorations- was rejected. In the literature, there are at least three rational reasons confirming the effectiveness of IDS on dentin bond strength. Firstly, freshly cut dentin is the ideal substrate for dentin bonding [20]. Various provisional cements had been used for patient's functional and esthetic needs. However, this procedure may lead to significant reduction in the bond strength owing to dentin contamination $[22,32,33]$. Secondly, the improved bond strength values of IDS could be explained by the prepolymerization of dentin bonding agents (DBAs). Dietschi et al.and McCabe et al reported that higher bond strength values were obtained in groups in which the infiltrating resin and the adhesive layer were polymerized first when compared to group in which DBA and the overlying composite were polymerized together $[34,35]$. These results could be explained by the collapse of the unpolymerized dentin-resin hybrid layer caused due to pressure exertion during composite placement or seating of the restoration [36]. Thirdly, IDS allows stressfree dentin bond development. Dentin bond strength develops progressively over time. Reis et al reported significant increase in the bond strength over a period of 1 week [37]. The above-mentioned reasons may be responsible for increased bonding durability achieved with IDS.

Another factor that may have contributed to a higher bond strength could be the DBA used during the IDS procedure. Clearfil SE Bond's demineralization depth is only about $1 \mu \mathrm{m}$. This level of demineralization ensures ideal dentin porosity for micromechanical adhesion and leaves hydroxyapatites on resin-dentin interface which are responsible for chemical bonding [38]. Additionally, Clearfil SE Bond's higher filler content among several adhesive systems may decrease polymerization shrinkage and generate more effective bonding [39].

Therefore, the application of a lowviscosity flowable composite on the adhesive layer may reduce gap formation at the dentinresin interface, thereby improving bond strength $[40,41]$. Andrade et al evaluated the bond strength and marginal adaptation of indirect 
restorations luted with the resin cement using three different dentin sealing techniques: (1) Conventional technique (one layer of adhesive) as group 1, (2) Dual bonding technique (two layers of adhesive) as group 2, and (3) Resin Coating Technique (adhesive + low-viscosity resin) as group 3 [27]. However, no significant differences were reported between the bond strengths of groups 2 and 3. Rocha et al evaluated the cuspal deflection of MOD cavities restored directly and indirectly with a nanoparticulate composite. They used glass-ionomer cement (GIC) and a flowable composite resin as the base materials. They obtained higher microstrain values in GIC groups; however, no differences were observed among the base materials studied [42].

Conversely, this study also compared the shear bonding performance of two resin-based luting cements in the presence of SPP. For this purpose, a conventional resin-based cement combined with a DBA RelyX Ultimate and a self-adhesive resin cement RelyX Unicem were tested. These cements were used for luting two restorative materials to the dentin: LAVA Ultimate (Resin-Based Nanoceramic [RNC]) and Solidex (IRC).

Dentinal adhesion is more complex because of its porous structure, wettability, and hydroxyapatite compositions in a collagen protein matrix. The micromechanical adhesion is the basic principle for bonding adhesive systems to dentin. Thus, the bonding effectiveness of the conventional resin cements were related with the hybridization quality generated by the DBAs applied to dentin surface [43]. In our experiment, SB was selected as a DBA to combine with RUL and tested for both the bonding protocols: etchand-rinse and self-etch. Our data indicated that acid-etched groups showed higher SBS than self-etched groups. However, there were no statistically significant differences between these groups ( $>00,005)$. Say et al reported results that are similar to the results of our investigation; however, unlike our findings, significantly higher values were achieved for etch-and-rinse technique regardless of the adhesive system used [44].
When the SEM photomicrographs were observed, the specimen bonded without acid etching revealed neither the hybrid layer nor the resin tags at dentin-resin interface. However, the specimen bonded with etch-and-rinse technique showed a uniform hybrid layer (Figure 4C). This finding is similar to the data generated by Monticelli et al and could explain improved bond strength values of acid-etched groups [45].

In the present study, significantly lower bond strength values were obtained from groups IDS+RUN+SOL and DDS+RUN+SOL. Many researchers have demonstrated similar findings [46-48]. The low bond strengths recorded for the self-adhesive cements are probably due to the cements' limited ability to remove the smear layer, which resulted in the formation of a weak hybrid layer between the resin cement and the dentin [45, 49]. Additionally, the bonding performance of self-adhesive cements could be related to their chemical interactions between the dentin hydroxyapatites [50, 51]. Han et al reported variable $\mathrm{pH}$ values for RUN immediately and 48 hours after polymerization [52]. Although an initial low $\mathrm{pH}$ is critical for the etching of dentin, if a low $\mathrm{pH}$ is observed for a long time, it may adversely affect the bonding of the mixed cements to dentin $[52,53]$.

Theresultsofthecurrentstudydemonstrated that resin-based materials luted to dentin with RUL had the highest SBS. It could be correlated to chemical content of SB Universal adhesive system. It contains 10_methacryloyloxydecyl dihydrogen phosphate (MDP) monomer and it was thought to be responsible for a durable adhesion to dentin [54]. Nevertheless, RUL also contains MDP in its composition and a previous study indicated that cements containing adhesive monomers have higher bond strengths when compared with other compositions [55]. This finding is in line with another previous study which demonstrated that ceramic core materials luted to dentin with RUL cement had the highest SBS [56].

It should be considered that the SBS was related with two interfaces (dentin-resin cement and resin cement-restorative material). Based 
on our data, the SBS values of the subgroups $\mathrm{A}+\mathrm{SB}+\mathrm{RUL}+\mathrm{SOL}$ and $\mathrm{SB}+\mathrm{RUL}+\mathrm{SOL}$ were found to be significantly higher than those of the subgroups A+SB+RUL+LAVA and SB+RUL+LAVA, in both IDS and DDS groups. However, the opposite of this situation was observed for RUN+SOL and RUN+LAVA subgroups. Thus, the second null hypothesis was accepted. This result could be associated with the amount of filler content of the restorative materials. The LAVA Ultimate resin contains $80 \%$ nanoceramic by mass, whereas the inorganic ceramic ratio of SOL is only 39\% [57]. Miyazaki et al demonstrated that the dentin bond strength of light-cured composites is directly proportional to their filler content, and found that the bond strength improves with increase in the filler content [58]. These findings may explain the significantly higher dentin bond strength for groups IDS+RUN+LAVA and DDS+RUN+LAVA. Conversely, Dalby et al mentioned that IDS application might have provided better adhesion when combined with RUN and they obtained the SBS test results of 6.94-10.03 Mpa using different DBAs [59]. However, this does not correlate with our findings. In our study, the results were between 10.22 to $19.74 \mathrm{Mpa}$. The reason for this discrepancy may be related to the specimen dimensions and geometry.

The longevity of IRCs relies mainly on the bonding system to provide an efficient and durable bond between the restorative material and the dentin substrate [60]. The IDS technique has been proposed to achieve this goal in the current study. Based on our findings, the selection of cement type and restorative material is also crucial for obtaining a high bond strength. However, it is also important to understand the mechanical behavior of IRCs to achieve long-lasting restorations. The literature shows that indirect resins with high elastic modulus concentrate stress in the restoration, generating less strain at the cusps and protecting the tooth [61].

The limitation of this study is that it is not possible to simulate the variable $\mathrm{pH}$ values, biomechanical conditions, and chemical changes in oral cavity. These factors are important for simulating the clinical scenario and should be investigated further in future in vitro studies.

\section{CONCLUSIONS}

Within the limitations of this in vitro experiment, we concluded the following:

1. The IDS process significantly increased the dentin bond strength. This result showed that the exposed dentin surface should be coated with IDS technique in order to make long-lasting indirect restorations;

2. In indirect restorations using Solidex as an IRC, RelyX Ultimate can be used for luting to achieve optimum bond strength. Nonetheless, RelyX Unicem may be preferred as a luting cement for CAD/CAM restorations fabricated with LAVA Ultimate resin.

\section{REFERENCES}

1. da Veiga AM, Cunha AC, Ferreira DM, da Silva Fidalgo TK, Chianca TK, Reis KRet al. Longevity of direct and indirect resin composite restorations in permanent posterior teeth: A systematic review and meta-analysis. J Dent. 2016;54:1-12. doi:10.1016/j.jdent.2016.08.003.

2. Cetin AR, Unlu N, Cobanoglu N. A five-year clinical evaluation of direct nanofilled and indirect composite resin restorations in posterior teeth. Oper Dent. 2013;38:E1-11. doi: 10.2341/12-160-C.

3. Ausiello P,Rengo S, Davidson CL, Watts DC. Stress distributions in adhesively cemented ceramic and resin-composite Class II inlay restorations: a3D-FEA study.Dent Mater 2004;20:862-872. doi:10.1016/j.dental.2004.05.001.

4. ManhartJ, Neuerer P,Scheibenbogen-Fuchsbrunner A, Hickel R. Three-year clinical evaluation of direct and indirect composite restorations in posterior teeth. J Prosthet Dent 2000;84:289-296. doi:10.1067/mpr.2000.108774.

5. van den Breemer CRG, Ozcan M, Cune MS, van der Giezen R, Kerdijk W, Gresnigt MMM. Effect of immediate dentine sealing on the fracture strength of lithium disilicate and multiphase resin composite inlay restorations. J Mech Behav Biomed Mater 2017;72:102-109. doi:10.1016/j.jmbbm.2017.04.002.

6. Nandini S. Indirect resin composites. JConserv Dent 2010;13:184-194. doi: 10.4103/0972-0707.73377.

7. Nishimaki M. Depth of cure and hardness of indirect composite materials polymerized with two metal halide laboratory curing units. J Oral Sci 2012;54:121-125. doi:10.2334/josnusd.54.121.

8. Saridag S, Helvacioglu-YigitD, Alniacik G, Ozcan M. Radiopacity measurements of direct and indirect resin composites at different thicknesses using digital image analysis. Dent Mater J2015;34:13-18. doi: 10.4012/dmj.2014-181.

9. Ruse ND, Sadoun MJ. Resin-composite blocks for dental CAD/CAM applications. J Dent Res 2014;93:1232-1234. doi:10.1177/0022034514553976.

10. Coldea A, Swain MV, Thiel N. Mechanical properties of polymer-infiltratedceramic-network materials. Dent Mater 2013;29:419-426. doi:10.1016/j. dental.2013.01.002.

11. Ishii N, Maseki T,Nara Y.Bonding state of metal-free CAD/CAM onlay restoration after cyclic loading with and without immediate dentin sealing. Dent Mater J 2017;36:357-367. doi:10.4012/dmj.2016-289. 
12. Della Bona A, Corazza PH,Zhang Y.Characterization of a polymer-infiltrated ceramic-network material. Dent Mater 2014;30:564-569. doi: 10.1016/j. dental.2014.02.019

13. Chen C, Trindade FZ, de Jager N, Kleverlaan CJ, Feilzer AJ. The fracture resistance of a CAD/CAM Resin Nano Ceramic (RNC) and a CAD ceramic at different thicknesses. Dent Mater 2014;30:954-962 doi: 10.1016/j. dental.2014.05.018

14. Sunico-Segarra M. SA:Classification of Resin Cements. In:APractical Clinical Guide to ResinCements. Berlin, Heidelberg: Springer;2015.

15. Burgess JO, Ghuman T,Cakir D. Self-adhesive resin cements. JEsthet Restor Dent 2010;22:412-419. doi: 10.1111//.1708-8240.2010.00378.x.

16. Loguercio AD, de PaulaEA, Hass V, Luque-MartinezI, Reis A, Perdigao J. A new universal simplified adhesive: $36-$ Month randomized double-blind clinical trial. JDent 2015;43:1083-1092. doi: 10.1016/j.jdent2015.07.005.

17. Amaral M, Belli R, Cesar PF, Valandro LF, PetscheltA, Lohbauer U. The potential of novel primers and universal adhesives to bond to zirconia. J Dent 2014;42:90-98. doi: 10.1016/j.jdent.2013.11.004.

18. Brigagao VC, Barreto LFD, Goncalves KAS, Amaral M, Vitti RP, Neves ACC et al. Effect of interim cement application on bond strength between resin cements and dentin: Immediate and delayed dentin sealing. J Prosthet Dent 2017;117:792-798. doi:10.1016/jprosdent.2016.09.015.

19. van den Breemer CR, Gresnigt MM, Cune MS. Cementation of GlassCeramic Posterior Restorations: A Systematic Review. Biomed Res Int 2015;2015:148954. doi: 10.1155/2015/148954.

20. MagneP.Immediate dentin sealing: a fundamental procedure for indirect bonded restorations. JEsthet Restor Dent 2005;17:144-154; discussion 155. doi: 10.1111/.j.1708-8240.2005.tb00103.x.

21. Santana VB, de Alexandre RS, Rodrigues JA, Ely C, Reis AF.Effects of Immediate Dentin Sealing and Pulpal Pressure on Resin Cement Bond Strength and Nanoleakage. Oper Dent 2016;41:189-199. doi: 10.2341/15-150-L.

22. Paul SJ, Scharer P.Effect of provisional cements on the bond strength of various adhesive bonding systems on dentine. J Oral Rehabil 1997;24:8-14. doi: 10.1046/.j.1365-2842.1997.00484.x

23. Cagidiaco MC, Ferrari M, Garberoglio R, Davidson CL. Dentin contamination protection after mechanical preparation for veneering. Am J Dent 1996;9:5760.

24. Magne P,Douglas WH. Porcelain veneers: dentin bonding optimization and biomimetic recovery of the crown. Int J Prosthodont 1999;12:111-121.

25. Magne P,Kim TH, Cascione D, Donovan TE. Immediate dentin sealing improves bond strength of indirect restorations. J Prosthet Dent 2005;94:511-519. doi: 10.1016/j.prosdent.2005.10.010.

26. Johnson GH, Hazelton LR, Bales DJ, Lepe X. The effect of a resin-based sealer on crown retention for three types of cement. J Prosthet Dent 2004;91:428435. do: 10.1016/S0022391304000770.

27. de Andrade OS, de Goes MF,Montes MA.Marginal adaptation and microtensile bond strength of composite indirect restorations bonded to dentin treated with adhesive and low-viscosity composite. Dent Mater 2007;23:279-287. doi: 10.1016/.jental.2006.01.028.

28. Sahin C, Cehreli ZC, Yenigul M, Dayangac B. In vitro permeability of etch-andrinse and self-etch adhesives used for immediate dentin sealing. Dent Mater $J$ 2012;31:401-408. doi: 10.4012/dmj.2011-217.

29. Duarte S, Jr, de Freitas CR, Saad JR, Sadan A. The effect of immediate dentin sealing on the marginal adaptation and bond strengths of total-etch and self-etch adhesives. JProsthet Dent2009;102:1-9. doi: 10.1016/S00223913(09)00073-0.

30. Choi YS, Cho IH. An effect of immediate dentin sealing on the shear bond strength of resin cement to porcelain restoration. J Adv Prosthodont 2010;2:3945. doi: 10.4047/jap.2010.2.2.39

31. Duarte RM, de Goes MF,Montes MA. Effect of time on tensile bond strength of resin cement bonded to dentine and low-viscosity composite.J Dent

\section{6:34:52-61. doi:10.1016/j.jdent.2005.03.002.}

32. Paul SJ, Scharer P.The dual bonding technique: a modified method to improve adhesive luting procedures. Int J Periodontics Restorative Dent 1997;17:536545.

33. Bertschinger C,Paul SJ, Luthy H, Scharer P.Dual application of dentin bonding agents: effect on bond strength. Am J Dent 1996;9:115-119.

34. McCabe JF, Rusby S. Dentine bonding--the effect of pre-curing the bonding resin. Br Dent J 1994;176:333-336. doi: 10.1038/sj.bdj.4808447.

35. Dietschi D, Herzfeld D. In vitro evaluation of marginal and internal adaptation of class II resin composite restorations after thermal and occlusal stressing. Eur J Oral Sci 1998;106:1033-1042. doi: 10.1046/j.0909-8836.1998.eos106609.x.

36. Frankenberger R, Sindel J, Kramer N, Petschelt A. Dentin bond strength and marginal adaptation: direct composite resins vs ceramic inlays. Oper Dent 1999;:24:147-155.

37. Reis A, Rocha de Oliveira Carrilho M, Schroeder M, Tancredo LL, Loguercio AD. The influence of storage time and cutting speed on microtensile bond strength. J Adhes Dent 2004;6:7-11.

38. Proenca JP, Polido M, Osorio E, Erhardt MC, AguileraFS, Garcia-Godoy Fetal. Dentin regional bond strength of self-etch and total-etch adhesive systems. Dent Mater 2007;23:1542-1548. doi:10.1016/j.dental.2007.02.001.

39. YesilyurtC, Bulucu B. Bond strength of total-etch and self-etch dentin adhesive systems on peripheral and central dentinal tissue: a microtensile bond strength test. J Contemp Dent Pract 2006;7:26-36.

40. Suzuki S. Clinical evaluation of a new resin composite crown system to eliminate postoperative sensitivity. Int J Periodontics Restorative Dent 2000:20:498-509.

41. Kitasako Y,Burrow MF,Nikaido T, Tagami J. Effect of resin-coating technique on dentin tensile bond strengths over 3 years. J Esthet Restor Dent 2002;14:115122. do: 10.1111/j.1708-8240.2002.tb00160.x

42. da Rocha DM, da Silva, J.M. F., May, L. G., Araújo, M. A. M., Di Nicoló, R., \& Rocha, J.C. Cuspal deflection of directly or indirectly restored teeth. Brazilian Dental Science 2013;16(4):34-40. doi:10.14295/bds.2013.v16i4.899.

43. Albaladejo $\mathrm{A}, 0$ sorio $\mathrm{R}$, Toledano $\mathrm{M}$, Ferrari M. Hybrid layers of etch-andrinse versus self-etching adhesive systems. Med Oral Patol Oral Cir Bucal 2010;15:e112-118. doi: 10.4317/medoral.15.e112.

44. Can Say E,Nakajima M, SenawongseP,Soyman M, Ozer F,Ogata Metal. Microtensile bond strength of a filled vs unfilled adhesive to dentin using self-etch and total-etch technique.J Jent 2006;34:283-291. doi:10.1016/j. jdent.2005.07.003

45. Monticelli F,Osorio R, Mazzitelli C,Ferrari M, Toledano M.Limited decalcification/diffusion of self-adhesive cements into dentin. J Dent Res 2008:87:974-979. doi: 10:1177/154405910808701012

46. Holderegger C, Sailer I,Schuhmacher C, Schlapfer R, Hammerle C, Fischer J.Shear bond strength of resin cements to human dentin. Dent Mater 2008:24:944-950. doi:10.1016/j.dental.2007.11.021.

47. Viotti RG, Kasaz A, Pena CE, Alexandre RS, Arrais CA, Reis AF.Microtensile bond strength of new self-adhesive luting agents and conventional multistep systems. J ProsthetDent 2009;102:306-312 doi: 10.1016/S00223913(09)60180-3.

48. Luhrs AK, Guhr S, Gunay H, Geurtsen W. Shear bond strength of self-adhesive resins compared to resin cements with etch and rinse adhesives to enamel and dentin in vitro. Clin Oral Investig 2010;14:193-199. doi:10.1007/s00784-0090279-z.

49. De Munck J, Vargas M, Van Landuyt K, Hikita K, Lambrechts P,Van Meerbeek B. Bonding of an auto-adhesive luting material to enamel and dentin. Dent Mater 2004:20:963-971. doi: 10.1016/.jdental.2004.03.002.

50. Yoshida Y,Nagakane K, Fukuda R, Nakayama Y,Okazaki M, Shintani Hetal. Comparative study on adhesive performance of functional monomers. J Dent Res 2004:83:454-458. doi: 10.1177/154405910408300604. 
51. Gerth HU,Dammaschke T,Zuchner H, Schafer E. Chemical analysis and bonding reaction of RelyX Unicem and Bifix composites--a comparative study. Dent Mater 2006;22:934-941. doi:10.1016/j.dental.2005.10.004.

52. Han L, Okamoto A, Fukushima M, Okiji T. Evaluation of physical properties and surface degradation of self-adhesive resin cements. Dent Mater J 2007;26:906-914. doi:10.4012/dmj.26.906.

53. Wang $Y$,Spencer P.Continuing etching of an all-in-one adhesive in wet dentin tubules. J Dent Res 2005;84:350-354. doi:10.1177/154405910508400411.

54. Flury S, Schmidt SZ, Peutzfeldt A, Lussi A. Dentin bond strength of two resin-ceramic computer-aided design/computer-aided manufacturing (CAD/ CAM) materials and five cements after six months storage. Dent Mater J 2016;35:728-735. doi: 10.4012/dmi.2016-095.

55. Blatz MB, Phark JH, Ozer F, ManteFK, Saleh N, Bergler M etal. In vitro comparative bond strength of contemporary self-adhesive resin cements to zirconium oxide ceramic with and without air-particle abrasion. Clin Oral Investig 2010;14:187-192. doi: 10.1007/s00784-009-0278-0.

56. Gundogdu $M, A$ Aladag $L I$. Effect of adhesive resin cements on bond strength of ceramic core materials to dentin. Niger J Clin Pract2018;21:367-374. doi: 10.4103/njcp.njcp 1017.
57. Soares CJ, Giannini M, Oliveira MT, Paulillo LA.Martins LR Effect of surface treatments of laboratory-fabricated composites on the microtensile bond strength to a luting resin cement. J Appl Oral Sci 2004;12:45-50. doi: 10:1590/ s1678-77572004000100009.

58. Miyazaki M, Hinoura K, Onose H, Moore BK. Effect of filler content of light-cured composites on bond strength to bovine dentine. J Dent 1991;19:301-303. do: 10.1016/0300-5712(91)90078-d.

59. Dalby R, Ellakwa A, Millar B, Martin FE. Influence of immediate dentin sealing on the shear bond strength of pressed ceramic luted to dentin with self-etch resin cement. Int J Dent 2012;2012:310702 doi: 10.1155/2012/310702.

60. Manso AP,Silva NR, Bonfante EA, Pegoraro TA, Dias RA, Carvalho RM. Cements and adhesives for all-ceramic restorations. Dent Clin North Am 2011;55:311-332 ix. doi:10.1016/.j.cden.2011.01.011.

61. Tribst.JPM, Dal Piva, A. M. D. 0., \& Borges, A. L. S. Biomechanical behavior of indirect composite materials: a 3D-FEA study. Brazilian Dental Science 2017;20(3):52-57.doi:10.14295/bds.2017.v20i3.1444.

\section{Bilal Utku Sag}

(Corresponding address)

Bahcelievler District, Adnan Kahveci Boulevard, No:141/2 Bahceliev-

Date submitted: 2019 Nov 05

ler Agiz ve Dis Sagligi Merkezi, Istanbul, TR 34180 